\title{
17. JURASSIC SCOLECODONT-LIKE MICROFOSSILS FROM THE FALKLAND PLATEAU (DEEP SEA DRILLING PROJECT, SITE 330)
}

\author{
F.H. Wind, M.G. Dinkelman, and S.W. Wise, Jr., \\ Antarctic Marine Geology Research Facility, Department of Geology, \\ Florida State University, Tallahassee, Florida
}

\begin{abstract}
Scolecodont-like microfossils, most of which are identified as cephalopod arm hooks (onychites), are common in Oxfordian sapropelic clays recovered at DSDP Site 330. All forms described are considered to represent pelagic organisms since stagnant bottom waters apparently precluded existence of significant bottom fauna. New taxa described are: Paraglycerites mediodenticulatus, n. sp., Accoluncus falklandensis, n. gen., n. sp., and Malvinensis decoris, n. gen., n. sp.
\end{abstract}

\section{INTRODUCTION}

Approximately 150 specimens of scolecodont-like microfossils were recovered from 42 samples from Cores 5 through 10 of DSDP Site 330 . The cores were taken between 300 and 414 meters subbottom depth on the Falkland Plateau in the South Atlantic (latitude $50^{\circ} 19^{\prime} \mathrm{S}$, longitude $46^{\circ} 53^{\prime} \mathrm{W}$ ). All samples are sapropelic clays which have been determined to be Oxfordian in age using calcareous nannoplankton (Wise and Wind, this volume) and palynomorphs (Harris, this volume).

A 15 to $20 \mathrm{~g}$ portion of each sample (wet weight) was disaggregated in distilled water and washed through $0.250 \mathrm{~mm}$ mesh screens. The wet material retained on the sieve mesh was then examined for microfossils using a fine-tipped brush to manipulate the residue. Each sample yielded some scolecodont-like material, although in many cases, such material consisted of unidentifiable fragments or carbonized plant remains. Several samples contained between 10 and 12 complete or nearly complete scolecodont-like objects. Complete specimens range in size from less than $1 / 2 \mathrm{~mm}$ to nearly 5 $\mathrm{mm}$ in length. The microfossils are dark brown to black in color, with a dull luster. Specimens were picked from residues and secured to circular cover slips with doublesided adhesive tape. Those cover slips selected for viewing on the scanning electron microscope were coated with carbon and gold palladium. All micrographs included in the accompanying plates were taken on an ISI Super-Mini scanning electron microscope. Specimens were generally well preserved when taken from the sediment, but upon drying, surfaces of many became crazed, and in time, large fissures developed. Holotypes and paratypes have been deposited at the U.S. National Museum (USNM).

\section{THE FAUNA}

Most specimens sufficiently complete for identification can be placed in Paraglycerites and Longuncus, two genera identified by Kulicki and Szaniawski (1972) as cephalopod arm hooks (onychites). Paraglycerites Eisenack, 1939, is characterized by a straight to arcuate long shaft, with spur and uncinus well developed. Longuncus Kulicki and Szaniawski, 1972, includes forms described as hooks with long, thin shafts, and a small uncinus and spur. These morphological features are identified in Plate 1, Figure 1.

Additional specimens represent a new genus, $A c$ coluncus, defined as small, gently arcuate forms bearing a small spur situated very close to an equally small uncinus. Other specimens appear to represent species of Deinuncus Kulicki and Szaniawski, 1972, and Urbanekuncus Kulicki and Szaniawski, 1972.

One large, well-preserved specimen cannot at this time be identified. This object, illustrated in Plate 6, bears no similarity to other specimens recovered in these samples and is unlike all scolecodonts and onychites previously described or illustrated. The uniqueness of this form has also been noted by Dr. Paul Tasch (1975, personal communication).

\section{PALEOECOLOGY}

In addition to species of onychites described herein, belemnite rostra, Inoceramus remains, several species of thin-walled pelecypods, agglutinated foraminifera, and plant debris occur in the claystone comprising Cores 5 through 10 of Site 330 . Bedding, where evident, is expressed as alternations of light and dark layers reflecting variation in calcareous nannoplankton and carbonaceous content. No apparent bioturbation is visible.

The sapropelic clay which characterizes the Oxfordian interval is believed to be the product of stagnant bottom conditions deficient in oxygen (see discussion of sedimentary regime by Thompson, this volume). Euxinic conditions favored the preservation of organic remains and explain the predominance of planktonic and pelagic organisms, whereas the absence of bioturbation suggests a poorly developed or nonexistent 
infauna. Thus the presence of deoxygenated bottom waters may explain the conspicuous absence of true scolecodonts (such as species of Ophryotrocha, Glycera, and Goniada which are found in the Middle and Upper Jurassic elsewhere in the world; Szaniawski, 1974). It may also be possible that the pelecypod fauna was more tolerant to generally inhospitable environmental conditions than scolecodont-bearing polychaetes.

\section{SYSTEMATIC PALEONTOLOGY}

Genus PARAGLYCERITES Eisenack, 1939

Paraglycerites mediodenticulatus Wind, Dinkelman, and Wise, n. sp. (Plate 1, Figures 1-4; Plate 2, Figures 1-8; Plate 3, Figures 1, 2)

Description: Specimens with straight shaft, large uncinus, and spur positioned at or near specimen midlength. Tip of spur may be slightly recurved. Spur and shaft bear fine-line ornamentation (Plate 1, Figures 3, 4).

Remarks: The complete specimens of this species range in length from approximately $1.4 \mathrm{~mm}$ to $4.9 \mathrm{~mm}$. This species differs from Paraglycerites necans Eisenack, 1939, P. gracilis Kulicki and Szaniawski, 1972, and $P$. erectus Kulicki and Szaniawski, 1972, in the medial placement of the spur.

Occurrence: Oxfordian.

Holotype: USNM 239440. Plate 1, Figures 1-4.

Paratypes: USNM 239441-USNM239447.

Type locality: Deep Sea Drilling Project Leg 36, Site 330 (latitude $50^{\circ} 55.19^{\prime} \mathrm{S}$; longitude $\left.46^{\circ} 53.00^{\prime} \mathrm{W}\right)$-Falkland Plateau: Sample 330 $6-4,18-20 \mathrm{~cm}$ (314.2 $\mathrm{m}$ subbottom depth).

\section{Paraglycerites necans Eisenack, 1939} (Plate 3, Figure 4)

Remarks: Position of spur and size of uncinus identifies this specimen as $P$. necans. Specimen length $1.27 \mathrm{~mm}$.

Occurrence: ?Triassic-Jurassic-?Cretaceous.

Genus URBANEKUNCUS Kulicki and Szaniawski, 1972

Urbanekuncus mediodenticulatus Kulicki and Szaniawski, 1972 (Plate 3, Figure 5)

Remarks: Although the base is not preserved, spur and uncinus configuration indicate that this specimen is $U$. mediodenticulatus. Specimen length $1.50 \mathrm{~mm}$.

Occurrence: Bathonian (Kulicki and Szaniawski, 1972)-Oxfordian (this paper).

Genus DEINUNCUS Kulicki and Szaniawski, 1972

\section{?Deinuncus sp.}

(Plate 3, Figure 7)

Remarks: Features of uncinus and shaft, and lack of spur are similar to species of Deinuncus. The laterally constricted basal opening of this specimen differs from the flaring basal opening which characterizes the two known species of this genus. Specimen length $2.3 \mathrm{~mm}$.

Genus ACCOLUNCUS Wind, Dinkelman, and Wise, n. gen.

Type species Accoluncus falklandensis Wind, Dinkelman, and Wise, n. sp.

Derivation of name: Latin accol (neighbor), uncus (hook, barb).

Diagnosis: Small specimens bearing short uncinus and spur of similar size. Spur situated adjacent to uncinus. Uncinus and shaft constitute single unit representing half of specimen length.

Remarks: This genus differs from other genera of onychites in the close placement of spur and uncinus.

\section{Accoluncus falklandensis Wind, Dinkelman, and Wise, n. sp.} (Plate 4, Figures 1-7)

Description: Gently curved specimens with rounded forwardly projecting spur adjacent to small similarly curved uncinus. Tip of uncinus may project perpendicular to hood axis or be slightly recurved. Base terminus is straight line or is deflected downward. Specimens are between 0.77 and $1.8 \mathrm{~mm}$ in length.

Occurrence: Oxfordian.

Holotype: USNM 239448. Plate 4, Figures 1-3.

Paratypes: USNM 239449, USNM239450.

Type locality: Deep Sea Drilling Project Leg 36, Site 330 (latitude $50^{\circ} 55.19^{\prime} \mathrm{S}$; longitude $46^{\circ} 53.00^{\prime} \mathrm{W}$ )-Falkland Plateau; Sample 330 $8-1,141-143 \mathrm{~cm}$ (348.9 m subbottom depth).

\section{Genus LONGUNCUS Kulicki and Szaniawski, 1972}

\section{Longuncus longus Kulicki and Szaniawski, 1972} (Plate 5, Figures 1-8)

Remarks: Specimens from Site 330 samples are very similar to those illustrated by Kulicki and Szaniawski (1972). However, specimens from the Falkland Plateau exhibit greater variability in that portion of the hook between the spur and base (the area referred to as the "supraopening area" by the previous authors).

Occurrence: Volgian (Kulicki and Szaniawski, 1972) to Oxfordian (this paper).

\section{INCERTAE SEDIS}

Genus MALVINENSIS Wind, Dinkelman, and Wise, n. gen.

Type species Malvinensis decoris Wind, Dinkelman, and Wise, n. sp.

Derivation of name: From Malvinas; Argentine name for the Falkland Plateau.

Diagnosis: Large, curved hook bearing sculptured surface, posterior terminating in two laterally compressed unequal keels.

Remarks: See remarks under Malvinensis decoris, n. sp.

Malvinensis decoris Wind, Dinkelman, and Wise, n. sp. (Plate 6, Figures 1-5)

Description: Specimens of this species consist of a relatively large (approximately $4.2 \mathrm{~mm}$ ) regularly curved hood terminating in a base formed of two rounded keels. The hook (or cusp) is ornamented for approximately half its length with fine undulatory sculpturing. The two keels are unequal in length; the inner keel is smaller and more round in profile than the distal keel (that projection which is in line with the convex side of the cusp). Although the sculptured part of the cusp is round in cross-section, the remainder of the specimen is laterally compressed. No pulp cavity is apparent.

Remarks: The lack of knowledge of phylogenetic affinity of this form complicates the detailed description, as little evidence exists to suggest proper orientation and function. Study of the micromorphology of this specimen reveals an absence of the surface striations which characterize onychites. Surfaces of both the ornamented cusp and keels are generally featureless, with the exception of occasional impressions of calcareous nannofossil components of the matrix (see Plate 6, Figure 5).

When the specimen is viewed from an oblique angle, a definite line can be seen differentiating the cusp and keel portions (see arrow, Plate 6, Figure 2). A micrograph at higher magnification of the line is shown as Plate 6, Figure 3. The authors interpret this lineation as representing the demarcation between that portion of the object which projected out of the soft tissue (the cusp) and the hypodermic portion of the specimen (the keels). The keels seem well designed to serve as muscle-support structures. Such features are not evident on any known scolecodonts, although the design of this specimen appears to have incorporated many of the combined features of annelid jaws and accompanying jaw carriers (ailerons).

Occurrence: Oxfordian.

Holotype: USNM 239451. Plate 6, Figures 1-5. 
Type locality: Deep Sea Drilling Project Leg 36, Site 330 (latitude $50^{\circ} 55.19^{\prime} \mathrm{S}$; longitude $\left.46^{\circ} 53.00^{\prime} \mathrm{W}\right)$-Falkland Plateau; Sample 330 6-2, 74-76 $\mathrm{cm}$ (310.7 m subbottom depth).

\section{ACKNOWLEDGMENTS}

We thank Mrs. Yang-Ja Chung for assisting in sample processing. Laboratory and facility support for M.G. Dinkelman and S.W. Wise were provided in part by COFRS (FSU) and by NSF Grants DES74-12369 and OPP74-20109 to $\mathrm{S}$.W. Wise.

\section{REFERENCES}

Eisenack, A., 1939. Einige neue Annelidenreste aus dem Silur und dem Jura des Balticums: Zeit. Geschiebeforsch. Flachlandgeol., v. 15, p. 153-176.

Kulicki, C. and Szaniawski, H., 1972. Cephalopod arm hooks from the Jurassic of Poland: Acta Palaeontol. Polonica, v. 17 , p. $379-426$.

Szaniawski, H., 1974. Some Mesozoic scolecodonts congeneric with Recent forms: Acta Palaeontol. Polonica, v. 19 , p. $179-200$. 
F. H. WIND, M. G. DINKELMAN, S. W. WISE, JR.

\section{PLATE 1}

Figures 1-4 Paraglycerites mediodenticulatus n. sp. Holotype. (USNM 239440). Sample 330-6-4, 18-20 cm (314.2

m).

1. $45 \times$.

2. Detail of spur. $180 \times$.

3. Detail of surface features of spur. $2700 \times$.

4. Surface of shaft below spur. $2800 \times$.

Figures 5, $6 \quad$ Paraglycerites sp. Sample 330-7-6, 124-126 cm.

5. Detail of spur. $2800 \times$.

6. $42 \times$. 
PLATE 1
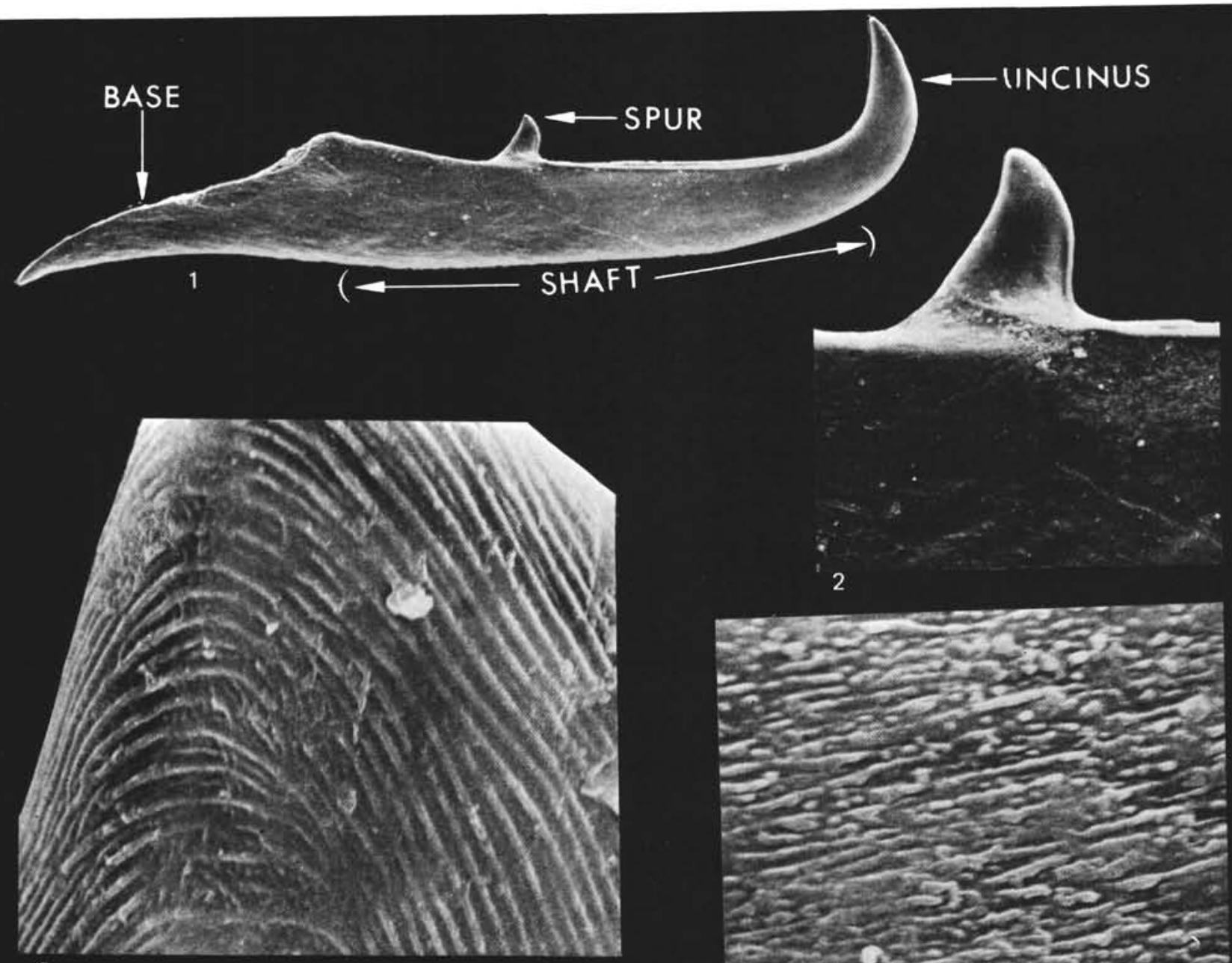

3
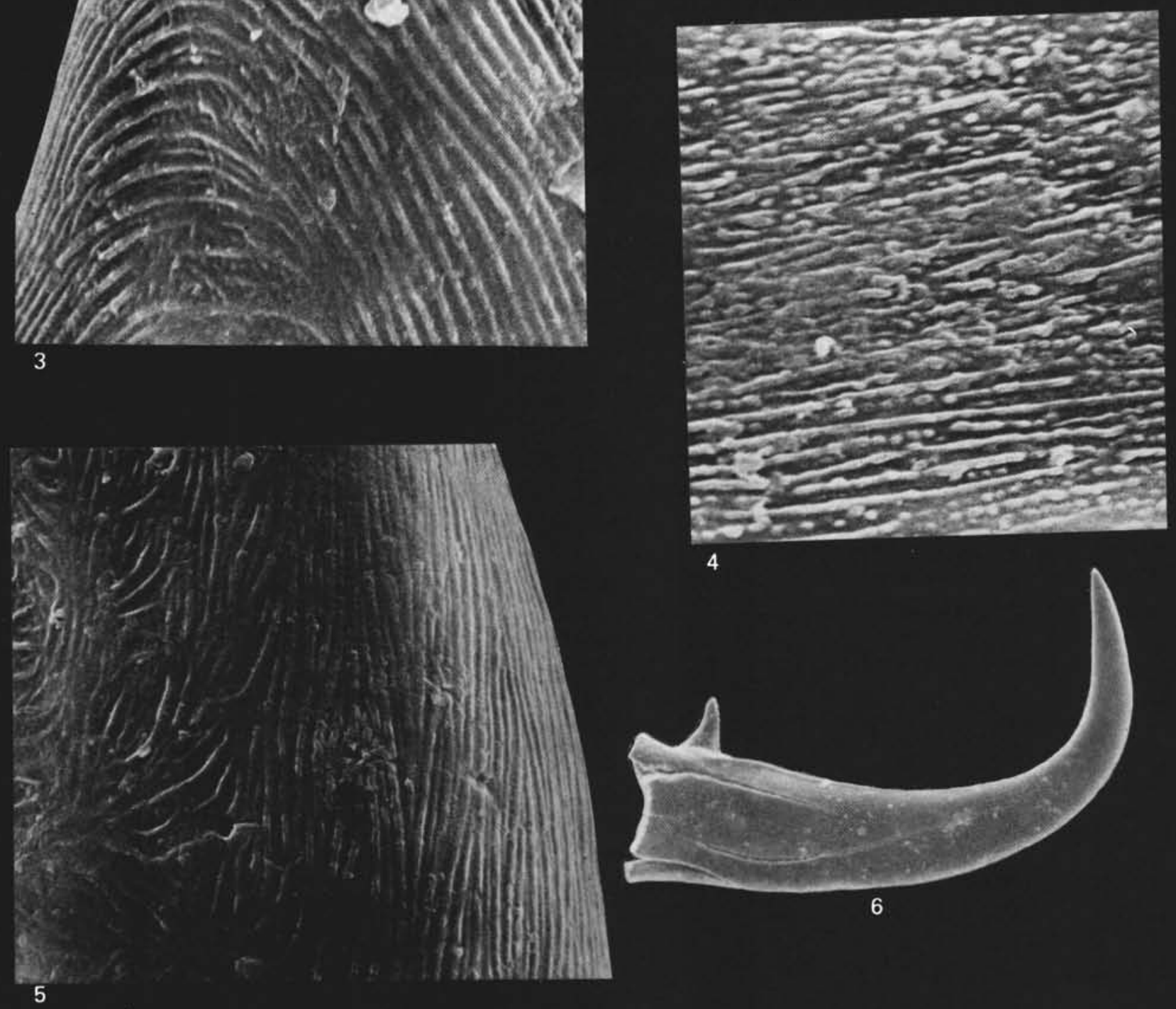
4

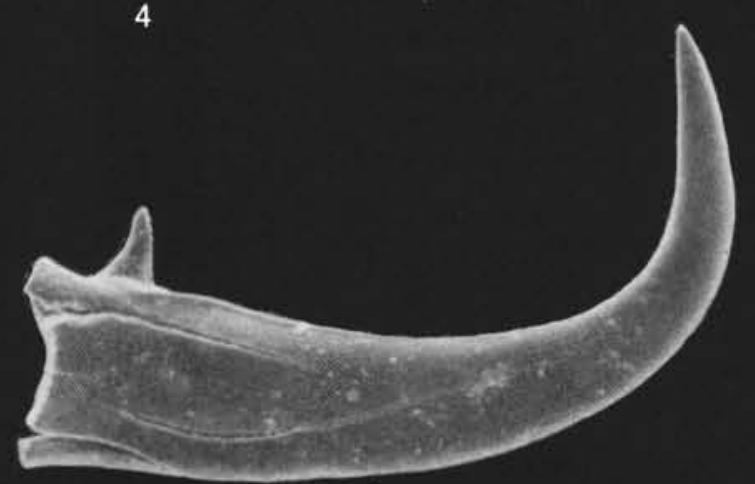

6 
F. H. WIND, M. G. DINKELMAN, S. W. WISE, JR.

\section{PLATE 2}

Figures 1-8 Paraglycerites mediodenticulatus n. sp. Paratypes. 1. (USNM 239441). Sample 330-7-4, 110-112 cm. $50 \times$.

2. (USNM 239442). Sample 330-6-2, $74-76 \mathrm{~cm}$. $45 \times$.

3. (USNM 239443). Sample 330-7-5, 63-65 cm. $37 \times$.

4. (USNM 239444). Sample 330-7-4, 118-120 cm. $30 \times$.

5, 8. (USNM 239445). Sample 330-8-1, 141-143 $\mathrm{cm}$.

5. $50 \times$.

8. Detail of surface between spur and uncinus. $2700 \times$.

6, 7. (USNM 239446). Sample 330-6-2, 74-76 cm.

6. $45 \times$.

7. Detail of base. $115 \times$. 
PLATE 2

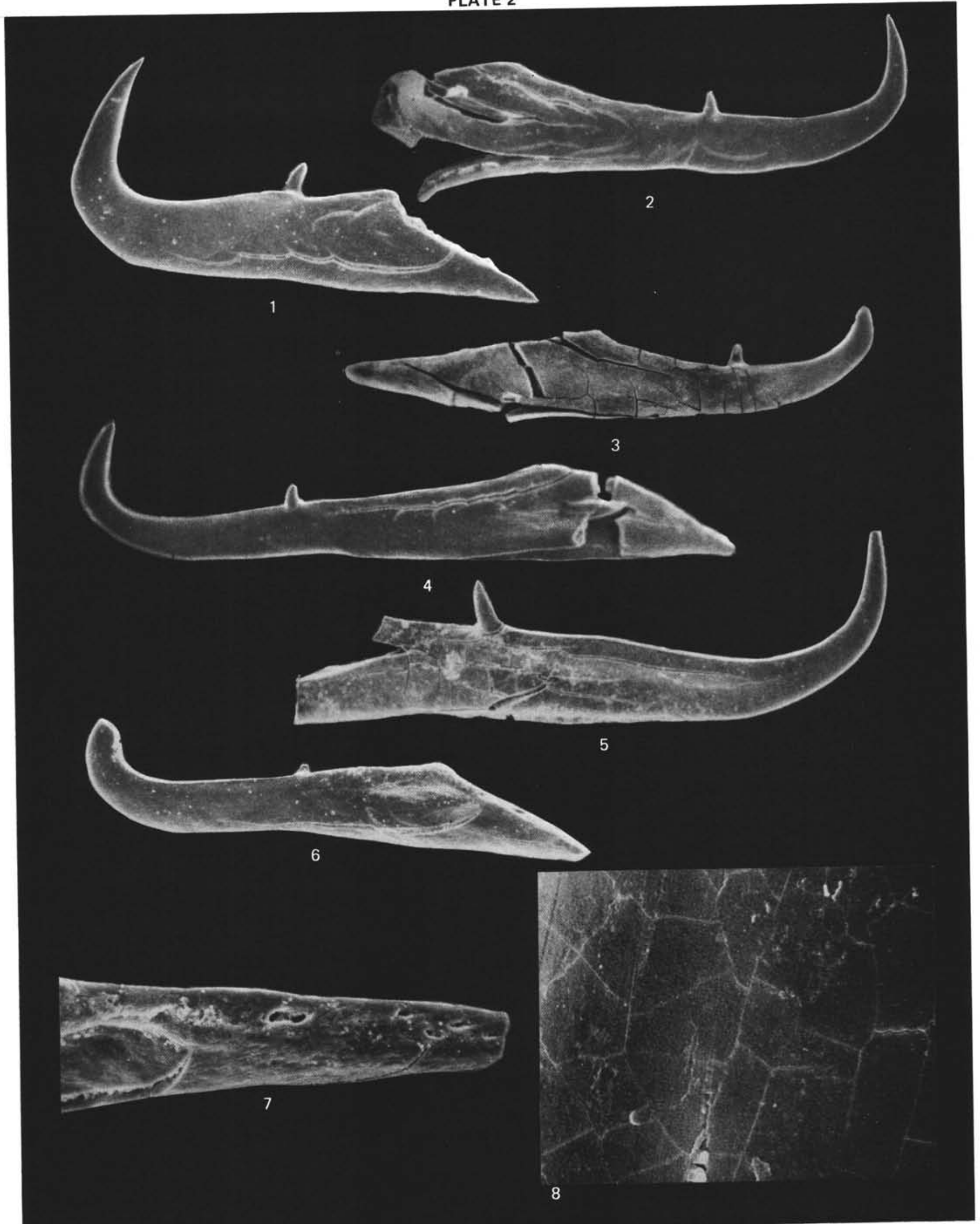




\section{PLATE 3}

Figures 1,2 Paraglycerites mediodenticulatus n. sp. Paratype. (USNM 239447). Sample 330-8-1, 141-142 cm.

1. Detail of spur. $3500 \times$.

2. $65 \times$.

Figure 3 Paraglycerites mediodenticulatus? Sample 330-7-1, $79-81 \mathrm{~cm} .45 \times$.

Figure $4 \quad$ Paraglycerites necans Eisenack, 1939. Sample 3306-2, 103-105 cm. 80x.

Figure $5 \quad$ Urbanekuncus mediodenticulatus Kulicki and Szaniawski, 1972. Sample 330-6-5, 9-11 cm. 60X.

Figure 6 Sharply curved uncinus-genus and species indeterminant. Sample 330-6-2, 6-8 cm. 85x.

Figure 7 ?Deinuncus sp. Sample 330-6-2, 74-76 cm. 50X. 
PLATE 3

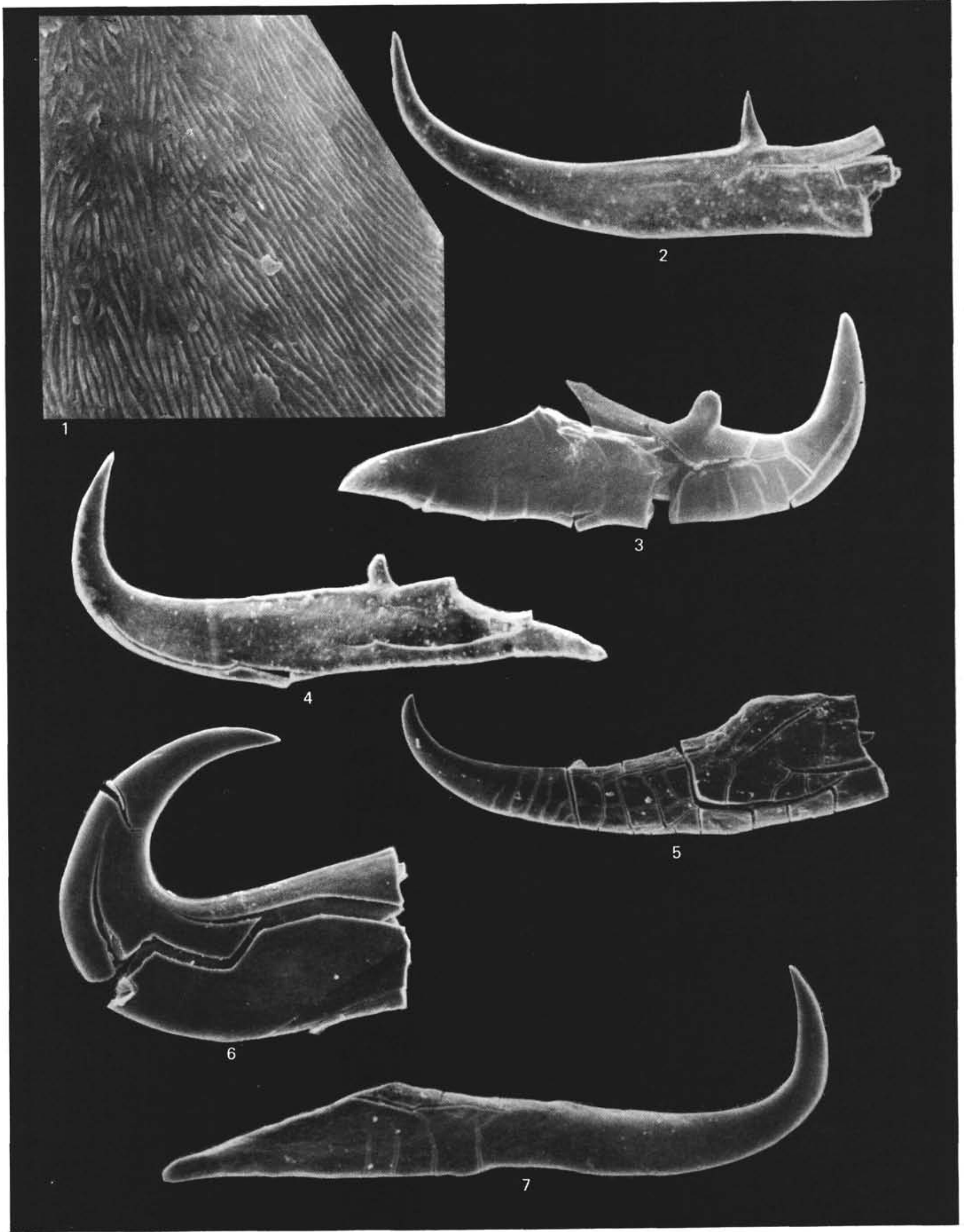


F. H. WIND, M. G. DINKELMAN, S. W. WISE, JR.

\section{PLATE 4}

Figures 1-7 Accoluncus falklandensis n. sp.

1-3, 6. Holotype. (USNM 239448). Sample 330-8-

$1,141-143 \mathrm{~cm}(348.9 \mathrm{~m})$.

1, 2. $125 \times$.

3. Detail of uncinus and spur. $600 \times$.

6. Surface striations of shaft between spur and uncinus. $2750 \times$.

4, 7. Paratype. (USNM 239449). Sample 330-8-1, $141-143 \mathrm{~cm}$.

4. $100 \times$.

7. Detail of surface between spur and uncinus. $3000 \times$.

5. Paratype. (USNM 239450). Sample 330-7-3, $121-123 \mathrm{~cm} .60 \times$. 


\section{PLATE 4}
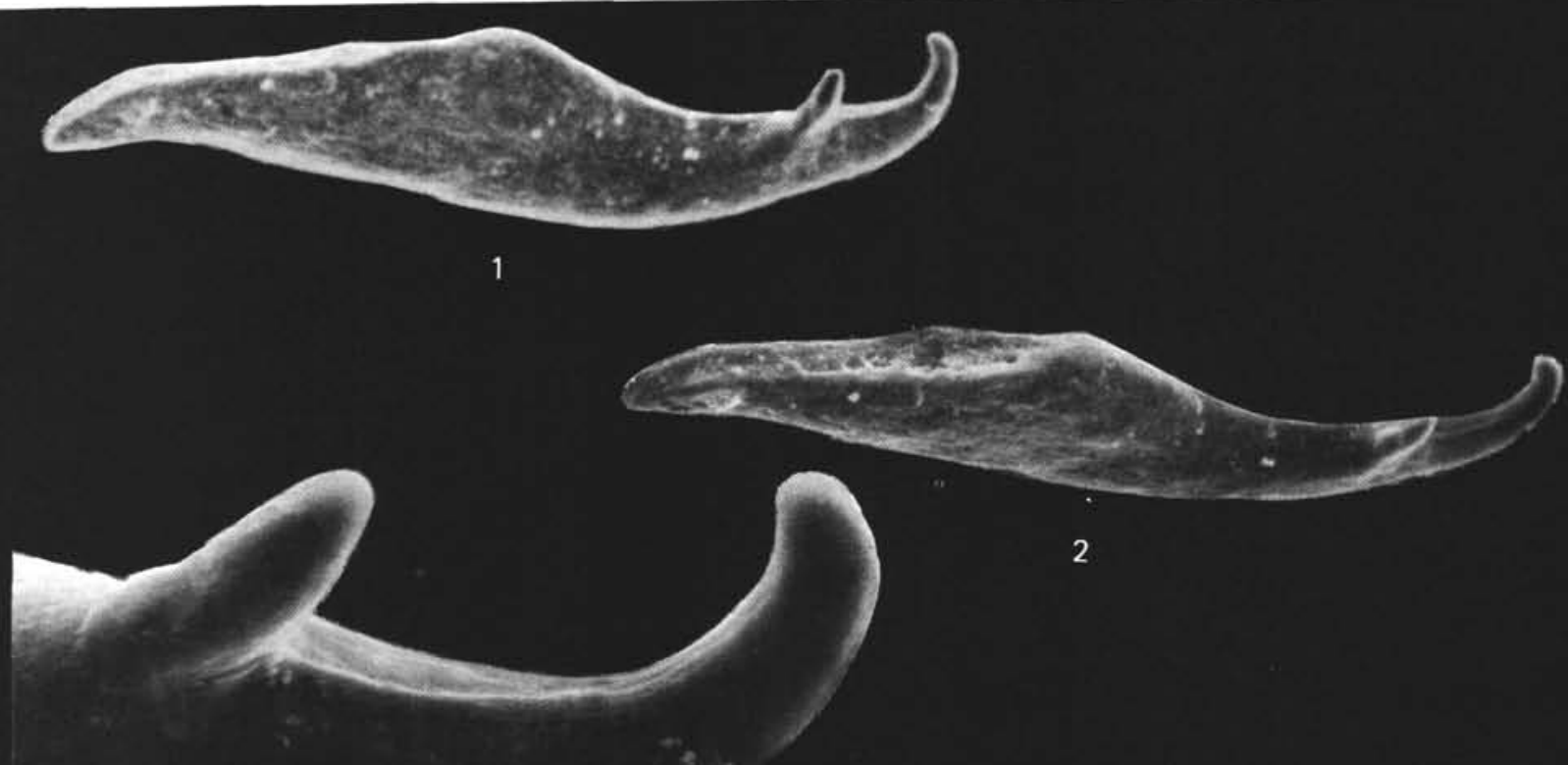

3

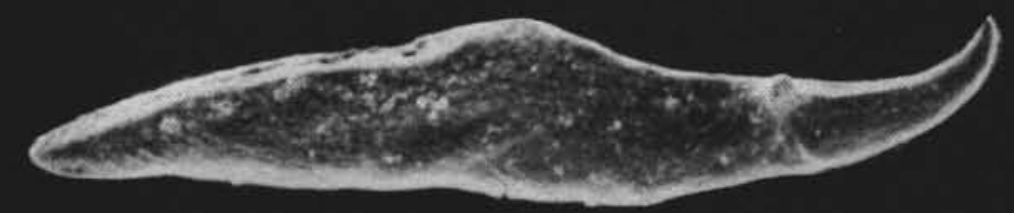

4

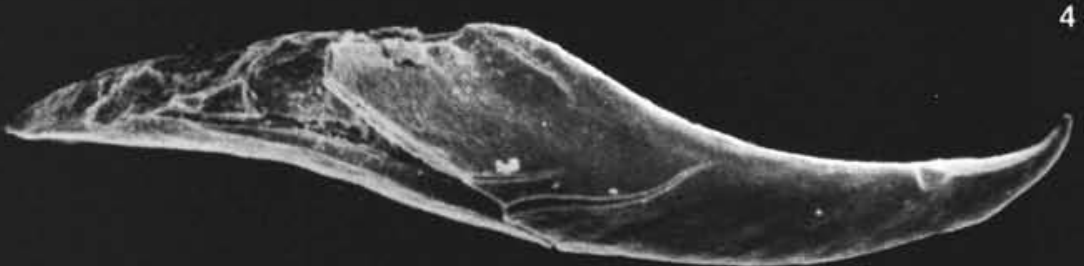

5
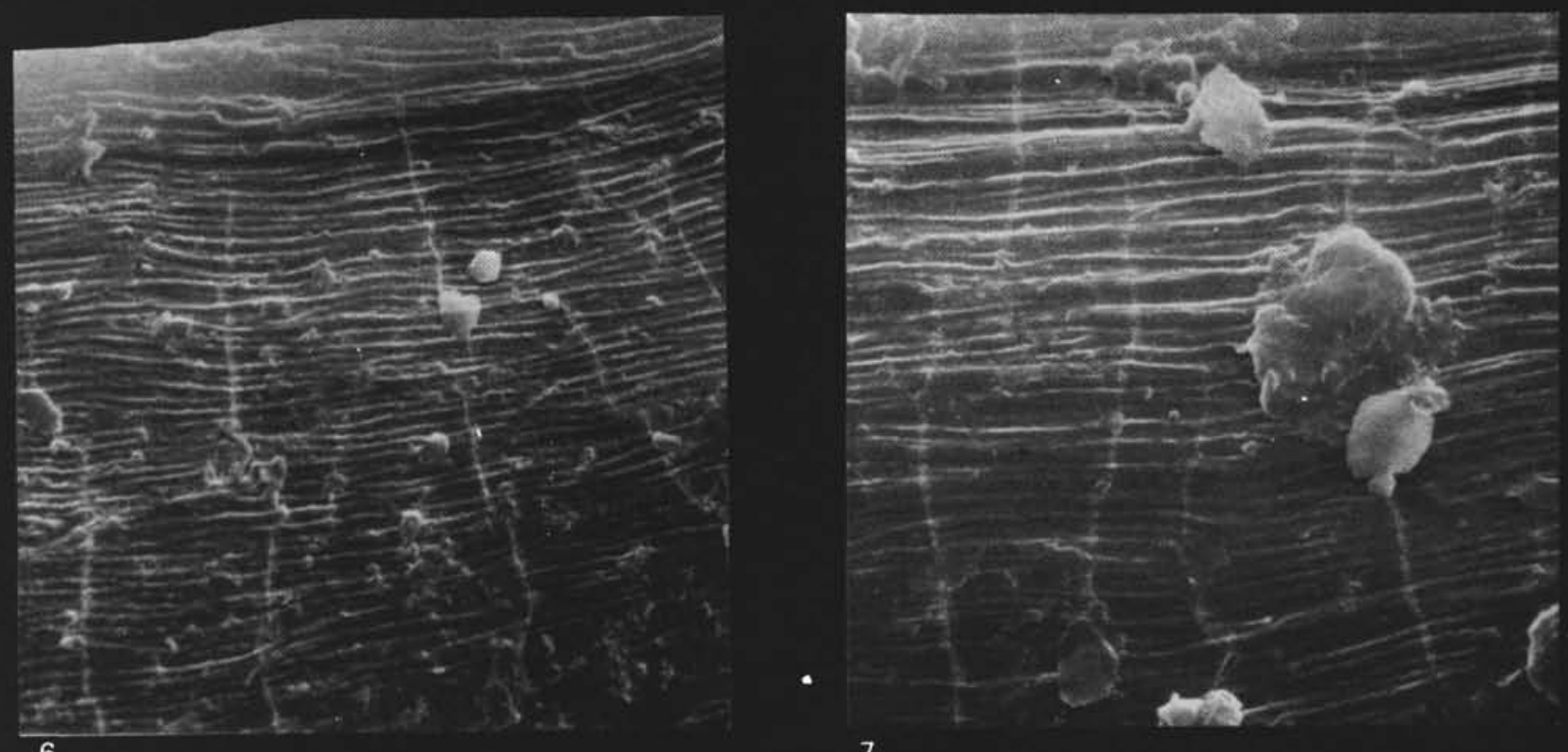
F. H. WIND, M. G. DINKELMAN, S. W. WISE, JR.

\section{PLATE 5}

Figures 1-8 Longuncus longus Kulicki and Szaniawski, 1972. Sample 330-6-5, 9-11 cm.

1, 2. $80 \times$.

3. Detail of uncinus and adjacent part of shaft. $550 \times$

4, 5. $48 \times$.

6. Detail of spur and adjacent part of shaft. $550 \times$.

7, 8. $90 \times$. 
PLATE 5
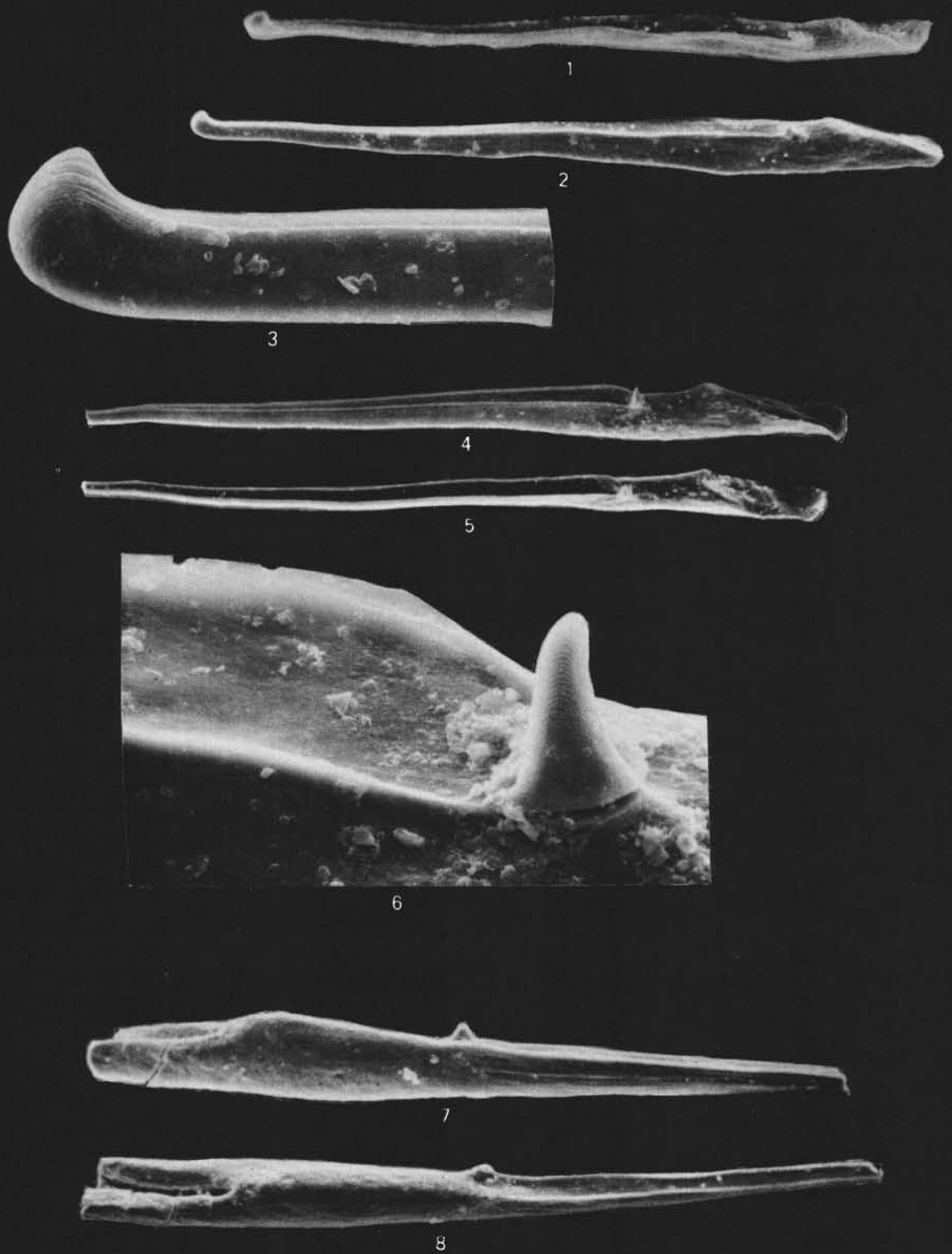


\section{PLATE 6}

Figures 1-5 Malvinensis decoris n. sp. Holotype (USNM 239451) Sample 330-6-2, 74-76 cm.

1,2. $30 \times$. Numbers on figures indicate placement and orientation of high magnification illustrations of surface detail (Figures 3-5). Arrow in Figure 2 indicates linear feature separating supposed exposed and hypodermic portions of the specimen.

3. Detail of linear feature (arrow) visible in Figure 2. $1440 \times$.

4. Detail of surface features of sculptured portion of cusp. $3300 \times$.

5. Detail of surface of specimen illustrating impression of coccolith. Impression is $5 \mu \mathrm{m}$ in diameter. $2100 \times$. 


\section{PLATE 6}
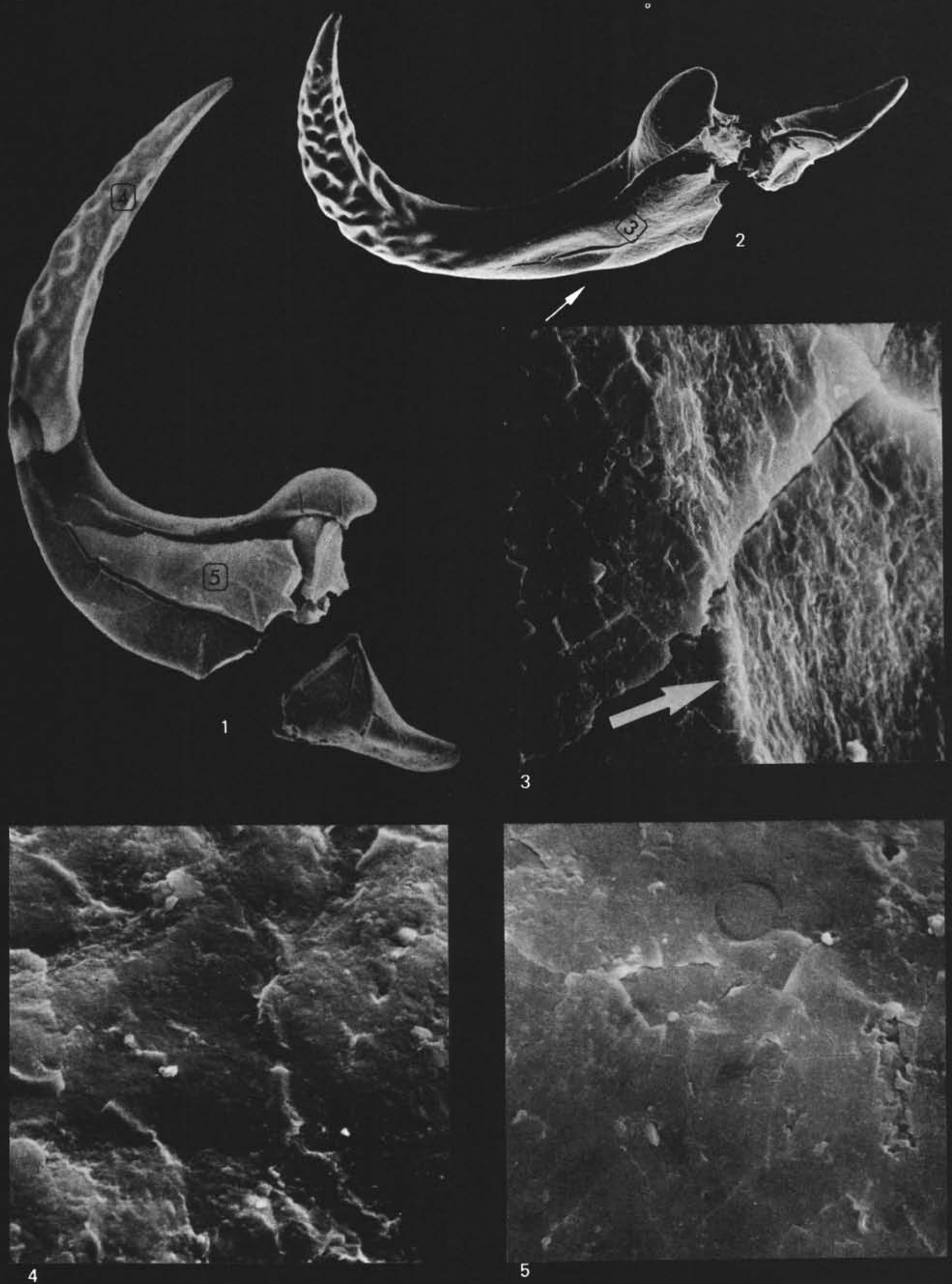